\title{
Problemas en la vestimenta en personas con discapacidad
}

\section{Clothing-related barriers in people with disability}

\section{Iván BARRIOS ${ }^{1}$, Aaron GENES ${ }^{2}$.}

${ }^{1}$ Estudiante de Medicina y Cirugía, Facultad de Ciencias Médicas, Universidad Nacional de Asunción, San Lorenzo - Paraguay.

${ }^{2}$ Estudiante de Diseño de Indumentaria, Facultad de Arquitectura Diseño y Arte, Universidad Nacional de Asunción, San Lorenzo - Paraguay.

Cómo citar este artículo: Barrios I, Genes A. Problemas en la vestimenta en personas con discapacidad. Medicina Clínica y Social. 2018;2(3):145-147.

\section{Estimado Editor,}

Como se sabe la salud de las personas no se limita al simple hecho de no padecer una enfermedad física, sino que es el resultado de un completo bienestar físico, social y mental; y es en los últimos puntos en los que queremos basar esta misiva, la salud psicosocial de las personas como componente fundamental de su funcionalidad como personas.

Ya se ha abordado que muchas veces la imagen corporal, o mejor dicho, la percepción que no tiene de su imagen corporal puede dañar la autoestima e incluso ser factor de riesgo para otras enfermedades mentales (1), por lo cual se pretende dar un resumen sobre lo que se ha investigado al respecto y brindar algunas soluciones, ya que mucho se ha investigado sobre las barreras ambientales, pero las barreras en cuanto a vestimenta han sido poco documentadas.

Las personas con discapacidad a menudo se enfrentan a un déficit de ropa y zapatos para adaptarse a las actividades en las que les gustaría participar, esto constituye una barrera en cuanto a la participación comunitaria (2). En una investigación realizada por Kabel y colaboradores se informa que el $32,7 \%$ ha rechazado alguna invitación porque no tenían ropa adecuada para el evento y así sentirse cómodos, el 61,9\% informa dificultades para transportarse a consecuencia de no poseer vestimenta adecuada; la falta de ropa atractiva y funcional puede ser perjudicial para el bienestar general si las personas no pueden presentarse de acuerdo con los estándares personales (3).

Algunos autores clasifican la discapacidad en dos modelos, el modelo físico y el social, en el físico se hace hincapié en la dificultad física de la persona, a su diagnóstico médico. El modelo social, sin embargo, se centra en la restricción social que se impone a la discapacidad corporal, en otras palabras, no es la discapacidad lo que impide que una persona participe plenamente en la sociedad, sino que es la sociedad la que crea barreras para la participación, un claro ejemplo es la dificultad de acceder a vestimenta adecuada para ciertos eventos, la persona puede participar de dichos eventos, pero no se siente cómoda por no poder acceder a vestimenta adecuada que cubra sus necesidades (4). 
Algunos autores enfatizan el hecho de que la vestimenta y la apariencia son factores importantes en la forma en que las personas sin discapacidades se comprometían con ellas, y que las discapacidades visibles aumentaban las barreras de actitud más negativas (4). Así que se vuelve al concepto anterior, el problema en sí no es la discapacidad sino las barreras que puedan ponerse para que dichas personas puedan acceder también a ropa y calzados adecuados para ellos y al mismo tiempo que cumplan los estándares estéticos de los mismos.

¿Qué se puede hacer para afrontar estas desigualdades? Lo más importante es tenerlos en cuenta y ofrecer el producto adecuado para estas personas, es donde las personas encargadas de diseñar vestimenta y calzados deben brindar sus conocimientos, puesto que sabemos de la existencia de ropa especial y calzados especiales para determinadas patologías, y estas pueden cubrir las necesidades físicas de los pacientes, pero, ¿qué ocurre con sus necesidades psicosociales?

Por ejemplo, una mujer a la que siempre le gustó vestir bien, debe quedarse en cama por alguna indicación médica, debo poder ofrecerse una vestimenta cómoda, pero también acorde a lo que la persona quiera, ya que, sumado al hecho de no poder moverse de la cama, podría no sentirse cómoda con su vestimenta y que la vean de esa forma.

Una solución para personas que están en cama, es por ejemplo optar por telas más resistentes, donde la persona pueda moverse en la cama sin miedo a que la ropa que está usando se rompa o maltrate. Es por ello fundamental el trabajo en equipo de médicos y kinesiólogos quieren brindarán las indicaciones médicas junto con alguien encargado de diseñar el vestuario y calzados de la persona. De esta forma los diseñadores tendrán información sobre los requisitos físicos que deben cumplir las prendas y brindar soluciones creativas acorde a los gustos del paciente.

Otra forma de visibilizar este problema, es concienciar a los diseñadores, o estudiantes de diseño a que presenten ideas o colecciones direccionadas a este tipo de público (personas con discapacidad) y también a aquellas que, a pesar de no tener una discapacidad, les puede resultar difícil encontrar ropa adecuada, como son las mujeres sometidas a mastectomía, personas usuarias de silla de ruedas, personas que utilizan muletas, personas que necesitan calzados ortopédicos, etc. Dado lo dicho anterior, se vuelve a recalcar, es fundamental el trabajo en equipo tanto de los profesionales médicos como de los diseñadores, para que se pueda lograr ofrecer a los pacientes algo que no cubra solo sus necesidades físicas, sino también contribuyan a una correcta funcionalidad psicosocial.

\section{CONFLICTOS DE INTERÉS Y FUENTE DE FINANCIACIÓN}

Los autores declaran no poseer conflictos de interés. Fuente de financiación: ninguna.

\section{REFERENCIAS BIBLIOGRÁFICAS}

1. Torales J, Barrios I, Amadeo G, Ebner B, Figueredo V, Garbett M, et al. Satisfacción corporal en bailarinas y no bailarinas. Mem Inst Investig En Cienc Salud. 2017;15(2):7984. http://dx.doi.org/10.18004/mem.iics/1812-9528/2017.015(02)79-084

2. Watson AF, Blanco J, Hunt-Hurst P, Medvedev K. Caregivers' perceptions of clothing for people with severe and profound intellectual disabilities. Percept Mot Skills. 2010;110(3 Pt 1):96 1-4. https://doi.org/10.2466/PMS.110.3.961-964 
3. Kabel A, Dimka J, McBee-Black K. Clothing-related barriers experienced by people with mobility disabilities and impairments. Appl Ergon. 2017;59:165-9. https://doi.org/10.1016/j.apergo.2016.08.036

4. McBee-Black K, Ha-Brookshire J. Exploring Clothing as a Barrier to Workplace Participation Faced by People Living with Disabilities. Societies. 2018;8(1):19. https://doi.org/10.3390/soc8010019 